\title{
Development of environmental model performance green productivity for small and medium industries
}

\author{
A S Cahyana ${ }^{1 *}$, H N Wahyuni ${ }^{1}$, and B I Putra ${ }^{1}$ \\ ${ }^{1}$ Departement of Industrial Engineering, Faculty of Engineering, Muhammadiyah \\ Sidoarjo University, Indonesia \\ *atikhasidhi@umsida.ac.id
}

\begin{abstract}
Small and Medium Industries has a very important role in supporting the Indonesian economy and reduce unemployment. SMEs in Indonesia contributed in employment amounted to $99.74 \%$ of the total national uptake and contribute as much as 1013.5 trillion or $56.73 \%$. As a country that is trying to give a full effort in implementing environmental management systems in all sectors of activity, we need to pay attention to the sector of Small and Medium Industries in terms of environmental management systems. Presumably most of the SMEs in Indonesia have never committed any good environmental management. On the other hand, good environmental management which is performed by company may help to improve efficiency, reduce excessive consumption of resources, reduce waste, help the company in meeting the requirements of environmental law, encourage employment to engage in environmental performance and improve company customer relationship. This study examines indicators that influences the ability of the environmental performance of food and beverage SMEs in East Java, and measure the effect of leadership on human resources, process and environmental management as well as the influence of process and environmental management of the Environmental Performance Indicator, to illustrate how the positive and negative effects of this research using Structural Equation Modeling (SEM) approach. Based on the t-value result, shows that significant variable is the leadership on the processes and environmental management, for human resources, process variables and environmental management of the Environmental Performance Indicator and Environmental Performance Indicator environmental performance.
\end{abstract}

Keywords: Small and medium industries (SMEs), Environmental Performance, Structural Equation Modeling (SEM)

\section{Introduction}

Development of Small and Medium Industry (SMEs) is very rapid, even SMEs able to survive when monetary year 2008. IKM also has a very important role in supporting the Indonesian economy and reduce unemployment. BPS data in 2015, that the contribution of SMEs on the increase of gross domestic product (GDP) of 56\% of total GDP in Indonesia (1). In addition to contribute GDP, SMEs also contributes in terms of employment, the role of SMEs in Indonesia contributes to the employment of $99.74 \%$ of the total national absorption and contributes 1,013.5 trillion or 56.73\% (2).

As a country that tries to give full effort in implementing environmental management system in all sectors of activities, we need to pay attention to Small and Medium Industry sector (SMEs) in terms of 
environmental management system. The desire to promote the national industry, especially small and medium industries, remains large despite the increase in emissions and B3 waste, along with the emergence of various problems as a result of efforts to promote the SMEs that is a physical or non physical impact, such as the occurrence of air pollution, water contamination, land pollution, problems caused by too much waste, and various non-physical problems such as loss of morale due to uncomfortable working conditions or environment (3).

Communities often relate environmental problems with environmental pollution. Yet environmental problems are much broader than environmental pollution, such as the use of materials that can poison or inflict pain on the part of employees, the use of natural resources, water, and excessive energy, while the availability of natural resources is increasingly limited and the quality is getting worst. These environmental issues can cause harm not only for the environment but also for business activities and the surrounding community. Losses incurred for business activities include declining productivity resulting from decreased employee health, increased operational costs caused by excessive use of raw materials, water and energy, the incidence of external costs caused by public complaints due to the impact of business activities. Therefore, it is necessary to do environmental management, especially work environment. This work environment includes production and nonproduction sites within the scope of activities.

Environmental performance is defined as a measurable outcome of an environmental management system, linked to organizational controls on environmental aspects, based on environmental policies, purposes and targets (ISO 14000), other definitions mentioned that environmental performance is an effective environmental outcome shown by the company, is the level of performance achieved, and how the company guarantees (4), impact of business activities. Therefore, it is necessary to do environmental management, especially work environment. This work environment includes production and non-production sites within the scope of activities.

The development of SMEs aims to make SMEs a national industrial base, in which to achieve this, the industry group is required to produce high quality products with competitive prices and able to keep the delivery schedule disciplined, both to meet the needs of consumers and to meet the supply for the industry.

SMEs as a business actor that produces various needs of life, unconsciously become one of the contributors cause of environmental damage. Negative impacts caused by SMEs occur from efforts to obtain raw materials, production processes, and waste generated either at the time of production or after. Efforts made by various parties including the government through ministries, agencies, and environmental observers both institutions and individuals seem to have not produced something very significant to reduce the rate of environmental damage. In reality, many SMEs have not been concerned about environmental issues, therefore a study is needed through a study in describing the real condition of SMEs related to environmental performance and productivity (5). In order to obtain an environmental performance model that adopts ISO 14000 clauses to improve the productivity of SMEs, as it greatly affects the quality of the products produced and supports to realize the development of national industry in 2025.

\section{Structural Equation Modelling (SEM) Method}

According to Ghozali and Fuad (6) in the complete modeling of SEM analysis, the steps are: (1). Conceptual Model, (2). Model Identification, (3). Parameter Estimation, (4). Testing statistics include (a) Confirmatory Factor Analysis (CFA), (b) The value of Chi Square, (c) Probability, (d) Root Mean Square Error of Approximation (RMSEA), (e) The value of the alignment index (Goodness of Fit Index/GFI). Structural Equation Modeling (SEM) is a set of statistical techniques that enable to test the relatively complex set of relationships simultaneously. The complex relationship can be constructed between one or several types of endogenous constructs with one of the exogenous construct (7). In order to communicate effectively the basic SEM concept ideas, it can be used path diagram as a means of communication. The path diagram can describe or specify the SEM model to be clearer and easier, especially when compared with using SEM mathematical model. In addition, a model trajectory diagram can help to simplify model conversion into commands or syntax of SEM 
software. Likewise, if the path diagram of a model is drawn correctly and following the prescribed rules, it can be derived from the mathematical model (8).

\section{Research methodology}

The data collection for this study relies on a questionnaire developed from 23 indicators used to measure latent variables in closed questions then distributed to the respondents who are the targeted samples. Assessment of respondents using Likert scale is widely used to measure attitudes, opinions, and perceptions (6). Respondents are asked to indicate the level of approval or disapproval of each question. In this study, the assessment was used by using 5 categories of assessment score scores represented by score 1 (strongly disagree), score 2 (disagree), score 3 (agree), and score 4 (strongly agree). Previous research ever done by Cahyana et al. (5) and in this research added productivity variable

The formulation of this research hypothesis is based on the result of the theoretical and empirical review presented as follows:

Hypothesis 1 : Leadership has a direct positive effect on environmental performance (9)

Hypothesis 2 : Leadership has a positive influence on environmental processes and management (9)

Hypothesis $3 \quad$ : Leadership has a positive influence on human resources (9)

Hypothesis 4 : Process and environmental management have a positive influence on Environmental performance indicator (EPI) (10)

Hypothesis 5 : Process and environmental management have a positive influence on environmental performance (9)

Hypothesis $6 \quad$ : $\quad$ Human resources have a positive influence on environmental performance (9)

Hypothesis 7 : Environmental performance indicator (EPI) has a positive influence on environmental performance (10)

Hypothesis 8 : Environmental performance has a positive effect on productivity

\subsection{Population and sample}

To clarify the number of respondents or the number of samples conducted field studies on the SMEs. The number of samples to be used in this study, the appropriate sample size for SEM analysis tools is between 100-200 respondents in order to be used in estimating interpretations with SEM (7). In addition, the determination of the minimum sample amount for SEM by Hair et al. (7) is dependent on the number of indicators multiplied by five to ten. Then the number of samples in this study are: Minimum sample size $=$ Number of indicators x $5=23$ x $5=115$ respondents. The number of samples to be used in this study amounted to 115 respondents. To clarify the number of respondents or the number of samples conducted field studies on the SMEs.

\section{Results and Discussion}

The big influence between variables had seen in the standardized solution model. The greater value of the relationship between the influences of the variables is better. Then the significance of the variables can be seen based on the t-value of the standarized loading factor $(\lambda)$ of the observed variables in the model. Variables that have t-value greater than | 1.96 | Is a significant variable in the formation of latent variables. The data processed using AMOS software. Obtained path diagram for the whole model where in the path diagram can be seen that there is no indicator showing standarized loading factor less than $|1.96|$, meaning that all indicators used to measure each latent variable value greater than $1.96 \mid$. Since the value of t-count is greater than t-table, the latent variables of the model compiler can be said to have a significant relationship. 


\subsection{Hypothesis testing}

For further test of causal relationships is to assess whether the research hypothesis accepted or rejected, the assessment is based on the value of t-value as shown in table 1.

Table 1. The value of t-value to the research hypothesis.

\begin{tabular}{|c|c|c|c|c|}
\hline No & Relationship & t-value & result & Hypothesis \\
\hline 1 & $\begin{array}{l}\text { Leadership has a direct positive effect on } \\
\text { environmental performance }\end{array}$ & 2.7 & Significant & H1 be accepted \\
\hline 2 & $\begin{array}{l}\text { Leadership has a positive influence on } \\
\text { environmental processes and management }\end{array}$ & 7.7 & Significant & H2 be accepted \\
\hline 3 & $\begin{array}{l}\text { Leadership has a positive influence on } \\
\text { human resources }\end{array}$ & 8.4 & Significant & H3 be accepted \\
\hline 4 & $\begin{array}{l}\text { Process and environmental management } \\
\text { have a positive influence on Environmental } \\
\text { performance indicator (EPI) }\end{array}$ & 6.5 & Significant & H4 be accepted \\
\hline 5 & $\begin{array}{l}\text { Process and environmental management } \\
\text { have a positive influence on environmental } \\
\text { performance }\end{array}$ & 7.4 & Significant & H5 be accepted \\
\hline 6 & $\begin{array}{l}\text { Human resources have a positive influence } \\
\text { on environmental performance }\end{array}$ & 3.5 & Significant & H6 be accepted \\
\hline 7 & $\begin{array}{l}\text { Environmental performance indicator (EPI) } \\
\text { has a positive influence on environmental } \\
\text { performance }\end{array}$ & 10.9 & Significat & H7 be accepted \\
\hline 8 & $\begin{array}{l}\text { Environmental performance has a positive } \\
\text { effect on productivity }\end{array}$ & 7.5 & Significant & H8 be accepted \\
\hline
\end{tabular}

To illustrate the results of this study illustrated in the conceptual model depicted in Figure.1

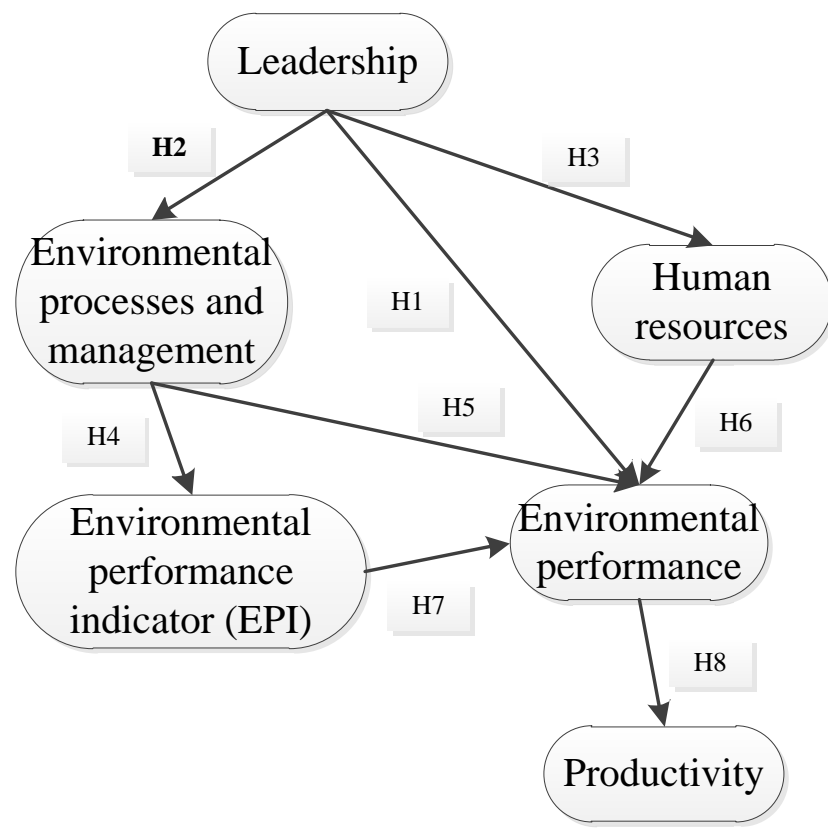

Figure 1. Conceptual Model of Research.

Source: Primary data is processed 


\section{Conclusions}

Based on the collecting, processing and analyzing the data that have been done, it can be concluded as follows: (1) this study analyzes the relationship of variables affecting Environmental Performance (KL) and the influence of Leadership (PL) Roles to Human Resources as well as the influence of the Leadership Role (PL) on the determinants of Process and Environmental Management (PM), as well as the influence ofProcess and management (PM) on the Environmental Performance Indicator (EP). (2). All significant variables affect the environmental performance (KL), also significantly affect the role of Leadership (PL) to Human Resources (SD), Role Leadership (PL) to Process and Environmental Management (PM), and Process and Management (PM) to Environmental Performance Indicator (EP), environmental performance against productivity (3). The role of Leadership in environmental performance is needed by SMEs in order to increase SME productivity to realize SMEs according to the regulation of environment minister of state concerning guidance and supervision of implementation of environmental management system, ecolabel, clean production, and environmentally sound technology in the region.

\section{Reference}

1. Badan Pusat Statistik (BPS). Perkembangan data Usaha Mikro, Kecil, Menengah (UMKM) dan besar tahun 2007-2008. Kementrian Koperasi dan Usaha Kecil dan Menengah; 2009.

2. International Organization for Standardization. Environmental management systems specification with guidance for use. Geneva, Switzerland: American National Standards Institute; 2004.

3. Singh RK, Murty HR, Gupta SK, Dikshit AK. Development of composite sustainability performance index for steel industry. Ecol Indic. 2007 Jul 1;7(3):565-88.

4. Hasibuan S, Hendra A. Penilaian kinerja lingkungan industri tekstil menggunakan metode Delphi dan fuzzy neural. In: Proceeding Seminar Nasional Teknik Industri dan Manajemen Produksi. Surabaya; 2002.

5. $\quad$ Sidhi Cahyana A, Subakti U, Noer B. Pengembangan Model Kinerja Lingkungan Bagi Industri Kecil dan Menengah (IKM) dengan Pendekatan Structural Equation Modeling (SEM). In: Simposium Nasional RAPI XI FT UMS. Surakarta; 2012.

6. Ghozali I, Fuad. Structural equation modeling: teori, konsep, dan aplikasi dengan Program LISREL 8.80. Semarang: Badan Penerbit Universitas Diponegoro; 2014.

7. Hair JF, Black WC, Babin BJ, Anderson RE TR. Multivariate data analysis. 6th ed. Prentice Hall; 2006.

8. Wijanto SH. Structural equation modeling dengan Lisrel 8.8 : konsep dan tutorial. Yogyakarta: Graha Ilmu; 2008.

9. Hussey DM, Eagan PD. Using structural equation modeling to test environmental performance in small and medium-sized manufacturers: can SEM help SMEs? J Clean Prod. 2007 Jan 1;15(4):303-12.

10. Rao P, la O' Castillo O, Intal PS, Sajid A. Environmental indicators for small and medium enterprises in the Philippines: An empirical research. J Clean Prod. 2006 Jan 1;14(5):505-15.

\section{Acknowledgments}

Thank you for Kemenristekdikti, Government and SMEs leaders in Sidoarjo for the assistance provided, and all parties who have helped and support the implementation of this research. 